\title{
Impact of home quarantine due to COVID-19 among Bangladeshi population
}

\author{
S.M. Mustofa Kamal ${ }^{1}$, Md. Feroz Kabir ${ }^{2}$, Mohammad Habibur Rahman ${ }^{3}$, Jalal Uddin ${ }^{4}$, Md. Sujon \\ Hosen $^{5}$, Shahida Sultana Shumi ${ }^{6}$, Md. Ahnaf Al Mukit ${ }^{7}$ \\ ${ }^{1}$ Department of Physiotherapy, SAIC College of Medical Science and Technology (SCMST), Bangladesh \\ ${ }^{1,2}$ Department of Physiotherapy and Rehabilitation, Jashore University of Science and Technology (JUST), Bangladesh \\ ${ }^{3}$ School of Science and Technology, Bangladesh Open University, Bangladesh \\ ${ }^{4,5,6}$ Department of Physiotherapy, SAIC College of Medical Science and Technology (SCMST), Bangladesh \\ ${ }^{7}$ Department of Physiotherapy, Centre for the Rehabilitation of the Paralysed (CRP), Bangladesh
}

\section{Article Info}

Article history:

Received Aug 23, 2020

Revised Dec 22, 2020

Accepted Jan 2, 2021

\section{Keywords:}

Corona virus

COVID-19

Economic impact

Physical impact

Psychological impact

\begin{abstract}
COVID-19 is an emergency public health issue and home quarantine can prevent the transmission. Quarantine restricts the people's mobility and it has a silent impact on physical, psychological and economical aspect. The purpose was to explore the impact of home quarantine among the general population in Bangladesh. This was a descriptive type of cross sectional survey with 600 samples from different district of Bangladesh by convenient sampling with a structured and language validated questionnaire. The results indicate the huge impact of home quarantine. Among 600 participants, $71.7 \%$ $(n=430)$ showed impact on their psychological health, 48.5\% $(n=291)$ physical health and $82.5 \%(\mathrm{n}=495)$ on their economy. Study showed strong association between gender and psychological impact $(\mathrm{p}<0.01)$ and very strong association between living area and their psychological impact $(p<0.00)$.There has also very strong association between their occupation and impact on their economy $(\mathrm{p}<0.00)$. Home quarantine has a progressive negative impact on the individual's psychological health, physical health and their economy. Individual's gender, living area and occupations are strongly associated with those negative impacts due to home quarantine. Supporting agency should take initiative to mitigate this all negative impacts of home quarantine and need to develop protocol for maintaining for health during quarantine time.
\end{abstract}

This is an open access article under the $\underline{C C B Y-S A}$ license.

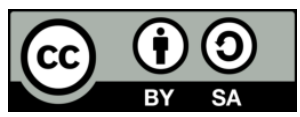

\section{Corresponding Author:}

S.M. Mustofa Kamal

Department of Physiotherapy

Saic College of Medical Science and Technology (SCMST)

Mirpur-13, Dhaka-1216, Bangladesh

Email:physiosohel@gmail.com

\section{INTRODUCTION}

Corona virus disease 2019 (COVID-19) is an emerging infectious disease caused by severe acute respiratory syndrome corona virus 2 (SARS-CoV-2) $1^{\text {st }}$ found within people in Wuhan city, Hubei Province, in China [1]. The emerging disease spreads fast through respiratory droplets or close contact [2] with an estimated $R_{0}$ of up to 5.7 (95\% CI: 3.8-8.9) [3].

WHO declared corona virus disease 2019 (COVID-19) as pandemic worldwide and Bangladesh is a part of this worldwide pandemic. COVID-19 caused by severe acute respiratory syndrome coronavirus-2 (SARS-CoV-2). In March 2020 the virus was confirmed to have spread in Bangladesh. On March 2020 the 
first three known cases were reported in Bangladesh by the country's epidemiology institute "Institute of Epidemiology, Disease Control and Research (IEDCR)" [4]. Infections remained low until the end of March but saw a steep rise in April [5]. In the week ending on 11 April, new cases in Bangladesh grew by $1.155 \%$, the highest in Asia, ahead of Indonesia, with $186 \%$ [6]. On $12^{\text {th }}$ June 2020 there have been recorded total 81,523 confirmed cases in Bangladesh, with 17,249 recoveries and 1,095 deaths [7]. Bangladesh declared a 10-day shut down on $22^{\text {nd }}$ March 2020 effective from 26 March to 4 April [5]. This was later increased to 30 May [8]. From $1^{\text {st }}$ June lockdown were relaxed and local transportation and office work allowed by maintaining health rules and social distancing.

Quarantine refers to separating and restricting the movement of people who are exposed to a contagious disease to see if they become sick, thus reducing their risk of infecting others [9]. Quarantine is often an unpleasant experience: loss of freedom, uncertainty over disease status, and boredom can create dramatic effects. The potential benefits of mandatory mass quarantine need to be weighed carefully against the possible long-term negative effects on human body both physically and mentally [10, 11].

Some negative psychological effects including post-traumatic stress symptoms, confusion, anger and depression are the common psychological impact due to quarantine has been reported recently [12]. Frustration, anger, anxiety are commonly affecting quarantined populations due to having inadequate basic supplies e.g. foods, water. [13]. Stroch [14] stated that individual with pre-existing mental health a condition has the possibilities to experiences their symptoms exacerbation; in other hands they may develop risk for adverse physical health consequences [15-17]. Due to SARS outbreak individual who required quarantine were experienced anxiety, acute stress, sleep disturbance and difficulty with making decisions [18]. Another study revealed the impact that 14 days quarantine for exposure to the Middle East Respiratory Syndrome had for its 1,692 participants and found that during their period of isolation, 7.6\% $(n=176)$ of individuals experienced symptoms of anxiety while 16.6\% $(n=275)$ expressed anger [19]. Current recommended COVID-19 precautions (i.e. quarantine, working from home, social distancing etc.) causing mental health problems. Mental health problems have negative impact on economy as individuals can't bear the cost of their treatment due to lack of accessibility, quality and unavailable cost [20].

Mental health problem is more among the peoples who are separated from their caregivers [21, 22]. Psychological development depends on the age of initial separation [23]. To prevent anxiety quarantined peoples are advised to make contact with their relatives/caregivers through phone call [24, 25]. Quarantined peoples developed confusion, fear, angry, anxiety etc. related to insomnia [26-29]. Another study says that economic loss due to quarantine may increase risk of psychological symptoms [19].

\section{RESEARCH METHOD:}

To meet up the objectives, a descriptive type of cross sectional study has been employed in the nearest district of Dhaka, Rajshahi and Chattogram divisions from $15^{\text {th }}$ March 2020 to $15^{\text {th }}$ May 2020. Six hundred (600) participants living in different district of Dhaka, Rajshahi and Chattogram divisions consented to participate in the study. People those were in home quarantine for at least 14 days they were the study populations. Before taking data consent was obtained from each participant. In addition, it was ensured that all information would only use for research purposes and was kept secure to researcher only. Data was recorded to mixed type of questionnaire by using depression anxiety stress scale-21(DASS-21) and selfadministered questionnaire form and finally analyzed by using updated SPSS software and Microsoft office excel. Psychological impact has measured by using DASS-21 scale [30], and also some impacts has measured by participants self-perception. Pearson Chi-square test was used to find the association between variables and result was expressed in table, Chi-value and $\mathrm{p}$-value (here significance level is $\mathrm{p}<0.05$ ). Inclusion criteria were age more than 18 years old, both male and female; those were mentally stable (mental stability assessed by self-developed verbal pre questions: Do you value yourself? Do you treat yourself with kindness and respects? Do you avoid self-criticism? Those gave answer positively we have collected data from that participants as a mentally stable participants) and undergo at least 14 days home quarantine. Those who were not willing to participate in the study and under 18 years old were excluded. The data was collected via both telephonic and face to face (by maintaining health rules) interview with a pre-piloted structured questionnaire with native language for getting accurate information. After obtaining the data all information was recorded in Microsoft 2010 with a password protected file and data input by independent data entry personnel to reduce bias. It was ensure the confidentiality of data and protected by primary investigator both soft and hard copy. An experienced statistician was helped to analyzed the data and association the analysis.

Int. J. Public Health Sci. Vol. 10, No. 1, March 2021: 1 - 7 


\section{RESULTS AND DISCUSSION}

Regarding the study, among 600 participants male was 475 (79.2\%) and female 125 (20.8\%), the mean age of the participants was 34.51 years, Most of the participants were from rural area $400(66.7 \%)$ rather than semi-urban $55(9.2 \%)$ and urban area $145(24.2 \%)$. Study showed that there were about 364 (60.7\%) participants from extended family and others from nuclear family. The mean income was monthly 20783.50 BDT and most of the participant's $(63.7 \%)$ monthly incomes were $<15000$ BDT. The education status was secondary school level in most of the participants as $165(27.5 \%)$ and illiterate was $32(5.3 \%)$. The study also showed that different types of job were the occupation of most of the participants as 199 (33.2\%) shows in Table 1.

The study showed strong association between gender and psychological impact $(\mathrm{p}<0.01)$ due to home quarantine shown in Table 2 and there are very strong association between living area of the participants and their psychological impact $(\mathrm{p}<0.00)$ as shown in Table 3.

Table 1. Socio-demographic status of the study

\begin{tabular}{|c|c|c|c|c|c|}
\hline Variable & $\begin{array}{c}\text { Frequency } \\
\text { and } \\
\text { percentage }\end{array}$ & & Variable & $\begin{array}{c}\text { Frequency } \\
\text { and } \\
\text { percentage }\end{array}$ & \\
\hline Gender & & \multirow{10}{*}{$\begin{array}{c}\text { Mean } \pm \text { SD } \\
34.51 \pm 12.914\end{array}$} & Marital Status & & \\
\hline Male & $475(79.2 \%)$ & & Married & $402(67 \%)$ & \\
\hline Female & $125(20.8 \%)$ & & Unmarried & $189(31.5 \%)$ & \\
\hline Age & & & Divorced & $3(0.5 \%)$ & \\
\hline$<25$ Years & $186(31 \%)$ & & Separated & $1(0.2 \%)$ & \\
\hline 25-35 Years & $208(34.7 \%)$ & & Widowed & $5(0.8 \%)$ & \\
\hline $36-45$ Years & $91(15.2 \%)$ & & Types of Family & & \\
\hline 46-55 Years & $66(11 \%)$ & & Nuclear & $236(39.3 \%)$ & \\
\hline$>55$ Years & $49(8.2 \%)$ & & Extended & $364(60.7 \%)$ & \\
\hline Living area & & & Monthly Income & & \\
\hline Rural & $400(66.7 \%)$ & & $<15000$ Taka & $382(63.7 \%)$ & \\
\hline Semi-urban & $55(9.2 \%)$ & & $15000-30000$ Taka & $148(24.7 \%)$ & Mean \pm SD \\
\hline Urban & $145(24.2 \%)$ & & $31000-45000$ taka & $35(5.8 \%)$ & $20783.50 \pm 59618.294$ \\
\hline Education status & & & $>45000$ Taka & $35(5.8 \%)$ & \\
\hline Illiterate & $32(5.3 \%)$ & & Occupation & & \\
\hline Can sign only & $14(2.3 \%)$ & & Job & $199(33.2 \%)$ & \\
\hline Primary & $128(21.3 \%)$ & & Business & $117(19.5 \%)$ & \\
\hline Secondary & $165(27.5 \%)$ & & Farmer & $26(4.3 \%)$ & \\
\hline Higher secondary & $112(18.7 \%)$ & & Day labor & $85(14.2 \%)$ & \\
\hline Degree & $127(21.2 \%)$ & & others & $173(28.8 \%)$ & \\
\hline Masters and above & $22(3.7 \%)$ & & & & \\
\hline
\end{tabular}

Table 2. Association between gender and psychological problem due to home quarantine

Association between Gender of the participants and facing psychological problem due to maintain home quarantine facing any psychological problem due to maintain

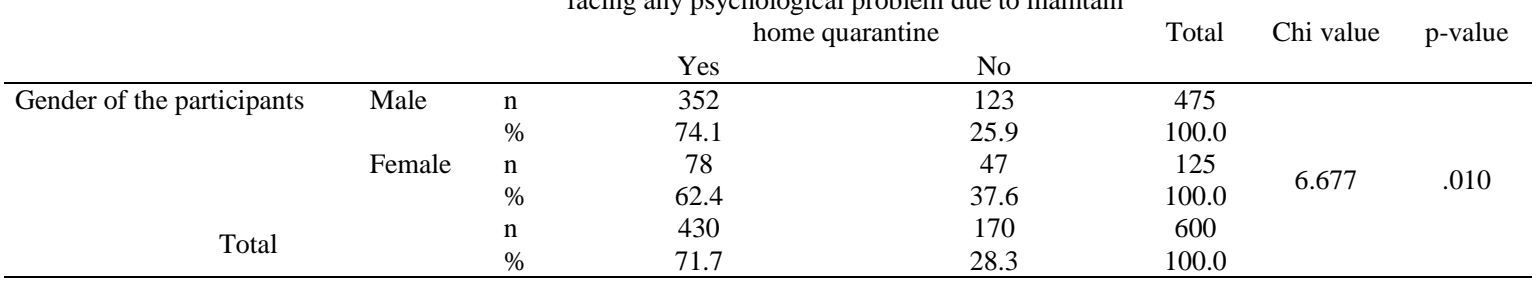

There were about 430 (71.7\%) participants showed their psychological impact due to home quarantine whereas 291 (48.5\%) showed physical impact and $495(82.5 \%)$ showed economic impact as shown in Table 4. Moreover it has been showed very strong association between individual's occupation and impact on their economy $(\mathrm{p}<0.00)$ indicated as shown in Table 5.

COVID-19 infection is increasing rapidly throughout the world and this is why WHO declared this is a pandemic. To prevent this corona virus transmission peoples are advised and forced to stay in quarantine (mostly in home quarantine). Due to this home quarantine peoples are suffering from physical, psychological and economic burden.

Within this study among 600 participants those were in home quarantine $79.2 \%(n=475)$ were male and $20.8 \%(n=125)$ were female. More participants age range were $25-35$ years $34.8 \%(n=208)$ and their mean age is 34.51 years. Most of them were home quarantine in their rural area $66.7 \%(n=400)$, Semi-urban region were $9.2 \%(n=55)$ and in Urban were $24.2 \%(n=145)$. Among all participants $5.3 \%(n=35)$ were 
illiterate, $2.3 \%(n=14)$ can sign only and rest of all were educated. Most of the participants were married $67 \%$ $(\mathrm{n}=402)$. Those were in home quarantine among them $60.7 \%(\mathrm{n}=364)$ were in extended family and $39.3 \%$ $(n=236)$ were in nuclear family. There were 33.2\% $(n=199)$ job holder and rest of all were businessman, day labor etc., and their mean income were 20,783 taka per month.

Table 3. Association between living area and psychological problem due to home quarantine

Association between living area of the participants and facing psychological problem due to maintain home quarantine facing any psychological problem due to

\begin{tabular}{|c|c|c|c|c|c|c|c|}
\hline & & & $\mathrm{ma}$ & & Total & Chi value & $\mathrm{p}$-value \\
\hline & & & Yes & No & & & \\
\hline & Rural & $\%$ & 67.8 & 32.3 & 100.0 & & \\
\hline Living area of the participants & Semi-urban & $\mathrm{n}$ & 52 & 3 & 55 & & \\
\hline & & $\%$ & 94.5 & 5.5 & 100.0 & 17523 & 000 \\
\hline & Urban & $\mathrm{n}$ & 107 & 38 & 145 & & \\
\hline Total & & $\mathrm{n}$ & 430 & 170 & 600 & & \\
\hline 10 ar & & $\%$ & 71.7 & 28.3 & 100.0 & & \\
\hline
\end{tabular}

Table 4. Impact of home quarantine

\begin{tabular}{|c|c|c|c|c|c|c|}
\hline \multicolumn{2}{|c|}{ Psychological impact } & \multicolumn{2}{|c|}{ Physical impact } & \multicolumn{2}{|c|}{ Economic impact } & \\
\hline Variable & $\begin{array}{l}\text { Frequency and } \\
\text { Percentage }\end{array}$ & Variable & $\begin{array}{l}\text { Frequency and } \\
\text { Percentage }\end{array}$ & Variable & $\begin{array}{l}\text { Frequency and } \\
\text { percentage }\end{array}$ & \\
\hline \multicolumn{2}{|c|}{$\begin{array}{c}\text { Facing psychological problem } \\
\text { during home quarantine } \\
\text { (If Yes than below all are } \\
\text { multiple response) }\end{array}$} & \multicolumn{2}{|c|}{$\begin{array}{l}\text { Physical symptoms } \\
\text { (If Yes than below all are } \\
\text { multiple response) }\end{array}$} & \multicolumn{2}{|c|}{$\begin{array}{l}\text { Impact on your income due to } \\
\text { home quarantine }\end{array}$} & \\
\hline Yes & $430(71.7 \%)$ & Yes & $291(48.5 \%)$ & Yes & $495(82.5 \%)$ & \\
\hline No & $170(28.3 \%)$ & No & $309(51.5 \%)$ & No & $105(17.5 \%)$ & \\
\hline \multicolumn{2}{|l|}{ Anxiety } & \multicolumn{2}{|c|}{ Excessive Sweating } & \multicolumn{2}{|c|}{ Specify, is it severe? } & \\
\hline Yes & $349(58.2 \%)$ & Yes & $4(0.7 \%)$ & Yes & $431(71.8 \%)$ & \\
\hline No & $83(13.8 \%)$ & No & $297(49.5 \%)$ & No & $64(10.7 \%)$ & \\
\hline \multicolumn{2}{|c|}{ Depression } & \multicolumn{2}{|c|}{ Head ache } & \multicolumn{2}{|c|}{ Got your salary in advance? } & \\
\hline Yes & $91(15.2 \%)$ & Yes & $65(10.8 \%)$ & Yes & $8(1.3 \%)$ & \\
\hline No & $341(56.8 \%)$ & No & $237(39.5 \%)$ & No & $191(31.8 \%)$ & \\
\hline \multicolumn{2}{|l|}{ Panicky } & \multicolumn{2}{|l|}{ Nausea } & \multicolumn{2}{|c|}{ Got your full salary? } & \\
\hline Yes & $266(44.3 \%)$ & Yes & $16(2.7 \%)$ & Yes & $81(13.5 \%)$ & \\
\hline No & $166(27.7 \%)$ & No & $285(47.5 \%)$ & No & $118(19.7 \%)$ & \\
\hline \multicolumn{2}{|c|}{ Restlessness } & \multicolumn{2}{|l|}{ Weakness } & \multicolumn{2}{|c|}{$\begin{array}{l}\text { How much portion of salary } \\
\text { you got? }\end{array}$} & \\
\hline Yes & $105(17.5 \%)$ & Yes & $80(13.3 \%)$ & No salary & $59(9.8 \%)$ & \\
\hline No & $327(54.5 \%)$ & No & $221(36.8 \%)$ & $\begin{array}{l}<15000 \\
\text { Taka }\end{array}$ & $48(8 \%)$ & Mean \pm SD \\
\hline \multicolumn{2}{|c|}{$\begin{array}{l}\text { Reduce concentration to any } \\
\text { task }\end{array}$} & \multicolumn{2}{|c|}{ Neck pain } & $\begin{array}{l}15000- \\
30000 \text { Taka }\end{array}$ & $3(0.5 \%)$ & $7541.29 \pm 47401.348$ \\
\hline Yes & $48(8 \%)$ & Yes & $108(18 \%)$ & $\begin{array}{l}>30000 \\
\text { Taka }\end{array}$ & $1(0.2 \%)$ & \\
\hline No & $384(64 \%)$ & No & $193(32.2 \%)$ & $\begin{array}{l}\text { Can you ma } \\
\text { cost by this }\end{array}$ & $\begin{array}{l}\text { ain your family } \\
\text { esent income? }\end{array}$ & \\
\hline \multicolumn{2}{|l|}{ Boredom } & \multicolumn{2}{|c|}{ Low back pain } & Yes & $203(33.5 \%)$ & \\
\hline Yes & $142(23.7 \%)$ & Yes & $103(17.2 \%)$ & No & $397(66.2 \%)$ & \\
\hline No & $290(48.3 \%)$ & No & $198(33 \%)$ & \multicolumn{2}{|c|}{ Expenses increased? } & \\
\hline \multicolumn{2}{|c|}{ Sleeping difficulties } & \multicolumn{2}{|c|}{ Pelvic pain } & Yes & $418(69.7 \%)$ & \\
\hline Yes & $38(6.3 \%)$ & Yes & $126(21 \%)$ & No & $182(30.3 \%)$ & \\
\hline No & $394(65.7 \%)$ & No & $175(29.2 \%)$ & Prices of dai & goods increased & \\
\hline Anger & & Fever & & Yes & $585(97.5 \%)$ & \\
\hline Yes & $75(12.5 \%)$ & Yes & $25(4.2 \%)$ & No & $15(2.5 \%)$ & \\
\hline No & $357(59.5 \%)$ & No & $276(46 \%)$ & $\begin{array}{l}\text { Faced any } p \\
\text { increased pr }\end{array}$ & $\begin{array}{l}\text { olems with this } \\
\text { in daily goods }\end{array}$ & \\
\hline Indigestio & & Loss of a & etite & Yes & $502(83.7 \%)$ & \\
\hline Yes & $64(10.7 \%)$ & Yes & $57(9.5 \%)$ & No & $82(13.7 \%)$ & \\
\hline No & $237(39.3 \%)$ & No & $244(40.7 \%)$ & & & \\
\hline Increase $\mathrm{d}$ & $\mathrm{g}$ addiction & Others & & & & \\
\hline Yes & $2(0.3 \%)$ & Yes & $13(2.2 \%)$ & & & \\
\hline No & $430(71.7 \%)$ & No & $288(48 \%)$ & & & \\
\hline
\end{tabular}

Int. J. Public Health Sci. Vol. 10, No. 1, March 2021: 1 -7 
Table 5. Association between Occupation of the participants and impact on income Association between Occupation of the participants and impact on income due to home quarantine Impact on income due to home

\begin{tabular}{|c|c|c|c|c|c|c|c|}
\hline & & & \multicolumn{2}{|c|}{ quarantine } & \multirow[t]{2}{*}{ Total } & \multicolumn{2}{|c|}{ Chi value $p$-value } \\
\hline & & & Yes & No & & & \\
\hline \multirow{10}{*}{$\begin{array}{l}\text { Occupation of the } \\
\text { participants }\end{array}$} & Job & $\mathrm{n}$ & 167 & 32 & 199 & \multirow{12}{*}{38.675} & \multirow{12}{*}{.000} \\
\hline & & $\%$ & $83.9 \%$ & $16.1 \%$ & $100.0 \%$ & & \\
\hline & Business & $\mathrm{n}$ & 100 & 17 & 117 & & \\
\hline & & $\%$ & $85.5 \%$ & $14.5 \%$ & $100.0 \%$ & & \\
\hline & Farmer & $\mathrm{n}$ & 26 & 0 & 26 & & \\
\hline & & $\%$ & $100.0 \%$ & $0.0 \%$ & $100.0 \%$ & & \\
\hline & Day labor & $\mathrm{n}$ & 82 & 3 & 85 & & \\
\hline & & $\%$ & $96.5 \%$ & $3.5 \%$ & $100.0 \%$ & & \\
\hline & Others & $\mathrm{n}$ & 120 & 53 & 173 & & \\
\hline & & $\%$ & $69.4 \%$ & $30.6 \%$ & $100.0 \%$ & & \\
\hline \multirow{2}{*}{ Total } & & $\mathrm{n}$ & 495 & 105 & 600 & & \\
\hline & & $\%$ & $82.5 \%$ & $17.5 \%$ & $100.0 \%$ & & \\
\hline
\end{tabular}

Brooks has reported negative psychological effects: post-traumatic stress symptoms, confusion, anger and depression are the psychological impact of quarantine [12]. Another study stated that frustration, anger, anxiety are commonly affecting quarantined populations due to having inadequate basic supplies e.g. foods, water etc. [13, 19]. They also expressed that among 1692 quarantined peoples $7.6 \%(n=176)$ of individuals experienced symptoms of anxiety while $16.6 \%(n=275)$ expressed anger.

This study shows that among 600 participants those were in home quarantine they are suffering from psychological symptoms $71.7 \%(\mathrm{n}=430)$. Among them all are suffering from one or more symptoms due to this negative impact of home quarantine. Study revealed that a large number of peoples developed anxiety $58.2 \%(n=349)$, Depression $15.2 \%(n=91)$, anger $12.5 \%(n=75)$, panicky $44.3 \%(n=266)$, restlessness $17.5 \%(\mathrm{n}=105)$, reduce concentration to any task $8 \% \quad(\mathrm{n}=48)$, sleeping difficulties $23.7 \%$ $(\mathrm{n}=142)$, increase drug addiction $0.3 \%(\mathrm{n}=2)$.

According to Stroch [14] individual with pre-existing mental health problem has the possibilities to experiences their symptoms exacerbation, in other hands due to quarantine they develop risk for adverse physical health consequences [15-17]. What consequences of physical health may occur they did not explore. In this study, result exploring that individual who were in home quarantine they developed physical health consequences as a negative physical health impact $48.5 \%(\mathrm{n}=291)$. Individuals are developed one or more physical health consequences were excessive sweating $0.7 \%(n=4)$, head ache $10.8 \%(n=65)$, nausea $2.7 \%$ $(n=65)$, neck pain $18 \%(n=108)$, low back pain $17.2 \%(n=103)$, pelvic pain $21 \%(n=126)$, fever $4.2 \%$ $(n=25)$, loss of appetite $9.5 \%(n=57)$. Wang found that individual who has psychological /mental health problems that leads great negative impact on economy as they can't bear treatment cost, lack of accessibilities, qualities and unavailable cost [20]. They did not figure out the reason strongly who leads these economic impacts.

This study figured the negative impact on economy who were in home quarantine and found that $82.5 \%(n=495)$ has greatly impacted their economy. Study explored the reason behind did not get salary in advance at the time of home quarantine $31.8 \%(n=191)$, did not get full salary $19.7 \%(n=118)$, their mean income were 7541 taka (within quarantine time), cannot maintain family cost by this present income $66.2 \%$ $(n=397)$, increases expenses $69.7 \%(n=418)$, prices of daily goods increase $97.5 \%(n=585)$. This finding is related to above finding by Wang [20]. COVID-19 has started speeding worldwide five months back and there has no significance evidence based data on association between impact of home quarantine and sociodemogrphic variables of the individuals. This study tried hard to establish is there any association between them or not.

Psychological impact is more in male $74.1 \%(n=352)$ rather than female $62.4 \%(n=78)$. There has strong association between gender and psychological impact due to home quarantine where chi-value 6.68 and $p$-value $(p<0.01)$. Those are living is rural area they developed more psychological symptoms and the living area is very strongly associated with psychological impact where chi-value 17.52 and $\mathrm{p}$-value $(\mathrm{p}<0.00)$. We did not find significant association between gender and physical impact due to home quarantine where we found the chi-value 1.78 and $p$-value $(\mathrm{p}<0.18)$. There are very strong association between individuals occupation and impact on their economy due to home quarantine where chi-value 38.67 and pvalue $(\mathrm{p}<0.00)$. Maintaining the family cost with this current income is also strongly associated with individuals occupation where chi-value 24.48 and $p$-value $(p<0.00)$. These findings express that occupation has great impact on individual economy and their daily living expenses. 


\section{CONCLUSION}

World Health Organization declares the COVID-19 as pandemic. Globally there have some suggestions for preventing the corona virus transmission where the home quarantine was chosen as one of the best method. This study was carried out to investigate the impact of home quarantine for at least 14 days. It has been found that home quarantine has negative impact to individual's mental/psychological health (depression, anger, lack of concentration are the common), physical health (head ache, neck pain, low back pain, pelvic pain, fever, loss of appetite are the common) and their economy (cannot maintain family cost, did not get full salary, increased daily expenses are common). This study also suggesting developing a protocol for preventing the home quarantine negative impact and ensuring the successful home quarantine.

\section{ACKNOWLEDGMENTS}

The authors acknowledge the department of Physiotherapy and rehabilitation, Jashore University of science and Technology (JUST) and Bangladesh Physiotherapy Association (BPA) who gave us continuous support and guidance.

\section{REFERENCES}

[1] Lu R., Zhao X., Li J., Niu P., Yang B., Wu H., et al., "Genomic characterisation and epidemiology of 2019 novel coronavirus: implications for virus origins and receptor binding," The Lancet, vol. 395, pp. 565-74, 2020.

[2] Xu XW, Wu XX, Jiang XG, Xu KJ, Ying LJ, Ma CL, et al., "Clinical findings in a group of patients infected with the 2019 novel coronavirus (SARS-Cov-2) outside of Wuhan, China: retrospective case series," BMJ, vol. 368, pp. 1-7, 2020, doi: 10.1136/bmj.m606.

[3] Sanche S., Lin $Y T$, Xu C., "High contagiousness and rapid spread of severe acute respiratory syndrome coronavirus 2," Emerging Infectious Disease., vol. 26, no. 7, pp. 1470-1477, 2020.

[4] Reuters, Bangladesh confirms its first three cases of coronavirus, 8 March 2020. Archived from the original on 27 March 2020. [Online]. Available: https://www.reuters.com/article/us-health-coronavirus-bangladeshidUSKBN20V0FS

[5] Dhaka Tribune. 20-fold rise in Covid-19 cases in Bangladesh since April 1. 14 April 2020. Retrived on 14 May 2020. https://www.dhakatribune.com/health/coronavirus/2020/04/14/20-fold-rise-of-covid-19-cases-in-bangladeshsince-april-1

[6] Parmet, W.E., Sinha, M.S., "Covid-19-the law and limits of quarantine,” New England Journal Medicine, vol. 382, p. e28, 2020, doi: https://doi.org/10.1056/NEJMp2004211.

[7] Institute of Epidemiology, Disease Control and Research (IEDCR), 2020. [Online]. Available: https://iedcr.gov.bd/

[8] Oman Observer. Bangladesh has extended lockdown by 11 days. 11 April 2020. [Online]. Available: https://www.omanobserver.om/bangladesh-has-extended-lockdown-by-11-days/.

[9] Centers for Disease Control and Prevention Quarantine and isolation. 2017. https://www.cdc.gov/quarantine/index.html

[10] Giubilini, A. Douglas, T. Maslen, H. Savulescu J., "Quarantine, isolation and the duty of easy rescue in public health," Developling World Bioethics, vol. 18, no. 2, pp. 182-9, 2018, doi: https://doi.org/10.1111/dewb.12165.

[11] Mattioli A.V., Nasi M., Cocchi, C., Farinetti A., "COVID 19 outbreak: impact of the quarantine-induced stress on cardiovascular disease risk burden," Future Cardiology, vol. 6, no. 6, pp. 1-4, 2020, doi: https://doi.org/10.2217/fca-2020-0055.

[12] Brooks, S.K., Webster, R.K., Smith, L.E., Woodland, L., Wessely, S., Greenberg N., "The psychological impact of quarantine and how to reduce it: rapid review of the evidence," The Lancet, vol. 395, no. 10227, pp. 912-20, 2020.

[13] Blendon R.J., Benson J.M., DesRoches C.M., Raleigh E., Taylor-Clark, K., "The public's response to severe acute respiratory syndrome in Toronto and the United States," Clincal Infectious Disease, vol. 38, no. 7, pp. 925-31, 2014.

[14] Storch E.A., Shah A., Salloum A., Valles N., Banu S., Schneider S.C., Goodman W.K., "Psychiatric diagnoses and medications for hurricane Harvey sheltered evacuees," Community Mental Health Journal, vol. 55, no. 7, pp. 1099$1102,2019$.

[15] Clay L.A., Goetschius J.B., Papas M.A., Kendra, J., "Influence of mental health on disaster preparedness: Findings from the behavioral risk factor surveillance system, 2007-2009," Journal of Homeland Security and Emergency Management, vol. 11, no. 3, pp. 375-392, 2014.

[16] Grant C., "Disaster preparedness to reduce anxiety and post-disaster stress (K4D Helpdesk Report)," Brighton, UK: Institute of Development Studies, 2018.

[17] Witthauer C., Gloster A.T., Meyer, A.H., Lieb R., "Physical diseases among persons with obsessive compulsive symptoms and disorder: A general population study," Social Psychiatry and Psychiatric Epidemiology, vol. 49, no. 12, pp. 2013-2022., 2014.

[18] Bai Y., Lin C.C., Lin C.Y., Chen J.Y., Chue C.M., Chou P., "Survey of stress reactions among health care workers involved with the SARS outbreak," Psychiatric Services, vol. 55, no. 9, pp. 1055-1057, 2014.

[19] Jeong H., Yim H.W., Song Y.J., Ki M., Min J.A., Cho J., Chae J.H., "Mental health status of people isolated due to Middle East respiratory syndrome," Epidemiology and Health, vol. 38, pp. 1-7, 2016. 
[20] Wang P.S., Gruber M.J., Powers R.E., Schoenbaum M., Speier A.H., Wells K.B., Kessler R.C., "Disruption of existing mental health treatments and failure to initiate new treatment after hurricane Katrina," The American Journal of Psychiatry, vol. 165, no. 1, pp. 34-41, 2018.

[21] WHO. The importance of caregiver-child interactions for the survival and healthy development of young children: A review. Geneva: World Health Organization; 2010.

[22] Norredam M., Nellums L., Nielsen R.S., Byberg S., Petersen J.H., "Incidence of psychiatric disorders among accompanied and unaccompanied asylum seeking children in Denmark: A nation-wide register-based cohort study," European Child Adolesccent Psychiatry, vol. 27, no. 7, pp. 439-46, 2018.

[23] Humphreys K.L., "Future directions in the study and treatment of parent child separation," Journal Clinical Child Adolescent Psychology, vol. 48, no. 1, pp. 166-78, 2019.

[24] MOHFW, Guidelines for Quarantine Facilities COVID-19- NCDC, 2020. [Online]. Available: https://ncdc.gov.in $>$ WriteRe...PDF guidelines For Quarantine facilities COVID-19-NCDC

[25] MOHFW, Advisory for Quarantine of Migrant Workers, Available: https://www.mohfw.gov.in/pdf/Advisoryforquarantineofmigrantworkers.pdf.

[26] Sprang G., Silman M., "Posttraumatic stress disorder in parents and youth after health-related disasters," Disaster Medicine Public Health Preparadness, vol. 7, no. 1, pp. 105-10, 2013.

[27] Reynolds D.L., Garay J.R., Deamond S.L., Moran M.K., Gold W., Styra R., "Understanding, compliance and psychological impact of the SARS quarantine experience," Epidemiology Infectious, vol. 136, no. 7, pp. 997-1007, 2018.

[28] DiGiovanni C., Conley J., Chiu D., Zaborski J., "Factors influencing compliance with quarantine in Toronto during the 2003 SARS outbreak," Biosecurity Bioterrorism, vol. 2, no. 4, pp. 265-72, 2014.

[29] Lee S., Chan, L.Y., Chau, A.M., Kwok K.P., Kleinman A., "The experience of SARS-related stigma at Amoy gardens," Social Science and Medicine, vol. 61, no. 20, pp. 38-46, 2015.

[30] Osman A., Wong, J.L., Bagge C.L., Freedenthal S., Gutierrez P.M., Lozano G., "The Depression Anxiety Stress Scales-21 (DASS-21): Further Examination of Dimensions, Scale Reliability, and Correlates," Journal of Clinical Psychology, vol. 68, no. 12, pp. 1-17, 2012. 